\title{
Paku Kawat Lycopodiella cernua (L.) Pic. Serm. (Lycopdiaceae-Lycopodiales) dari Provinsi Riau - Kajian Morfologi dan Sekuen DNA berdasarkan Primer RBCL
}

\section{Club Moss Lycopodiella cernua (L.) Pic. Serm. (Lycopdiaceae-Lycopodiales) From Riau Province - Morphological Study and Its DNA Sequence Based on RBCL Primer}

\section{Nery Sofiyanti, Mayta Novaliza Isda}

Jurusan Biologi Fakultas Matematika dan Ilmu Pengetahuan Alam Universitas Riau Kampus Bina Widya Jl. Pekanbaru Bangkinang KM 12.5, Panam, Pekanbaru, Riau. 28295. Email : nery.sofiyanti@lecturer.unri.ac.id

\begin{abstract}
Moss club (Lycopodiella cernua) is one of fern members distributed in Riau Province. The aimed of this study were to characterized the morphological characters and to analized its DNA sequence based on rbcl primer. Samples were collected from the field, documented and characterized the morphological charaters. DNA were isolated and amplified using PCR method and rbcl primer. DNA sequnces were then analized using BLAST Lycopodiella cernua collected from Riau Province was characterized by having creeping and erect rhizome that covered by microphyl, and terminal strobili. Rbcl fragmen of Lycopodiella cernua was sucssesfully amplified with 643 bp length. BLAST result confirmed the rbcl fragmen of this club moss.
\end{abstract}

Keywords: club moss, DNA, morphology, rbcl.

\section{Pendahuluan}

Paku kawat Lycopodiella cernua merupakan salah satu paku yang mempunyai daun bertipe mikrofil yang ditemukan di Provinsi Riau (Sofiyanti et al. 2015). Jenis ini tergolong dalam Famili Lycopodiaceae, Ordo Lycopodiales (Wikstrom \& Kenrick 2000) kelas Lycopsida. Pada umumnya anggota Lycopodiaceae mempunyai karakteristik rizom yang menjalar dengan cabang tegak, daun kecil dan menyerupai sisik tersusun pada seluruh permukaan batang, sporangia tersusun terminal pada ujung cabang membentuk strobilus (Zhang \& Iwatsuki 2013).

Lycopodiella cernua pada umumnya merupakan paku helofit, yaitu paku yang hidup pada habitat yang sedikit berair (Zhang \& Iwatsuki 2013). Namun inventarisasi paku ini di Provinsi Riau menunjukan adanya tipe habitat yang berbeda, yaitu terestrial pada daerah terbuka maupun ternaungi serta pada daerah berair (helofit) (Sofiyanti et al. 2015; Sofiyanti \& Isda 2017 dan 2018. Unpubl.).

Dewasa ini, kajian sistematika tumbuhan termasuk tumbuhan paku telah menggunakan pendekatan data molekuler yang berkaitan dengan karakteristik pita atau pun sekuen DNA. Salah satu penanda DNA untuk mengetahui karakteristik sekuen $\mathrm{DNa}$ adalah ribulose-1,5bisphosphate carboxylase/oxygenase large subunit (rbcl) (Gielly \& Taberlet 1994; Wikstrom \& Kenrick 2000, 2001, 2008; Ebihara 2011; Bafeel et al. 2012) karena menunjukan adanya variasi sekuen pada jenis yang berbeda sehingga dapat digunakan dalam identifikasi dan klasifikasi tumbuhan termasuk tumbuhan paku (Hasebe 1995).

Pada golongan tumbuhan paku, analisis DNA dengan primer rbcl telah dilakukan pada Famili Hymenophyllaceae, genus Trihomanes (Dubuisson et al. 2003) serta Famili Cyatheaceae, Lycopodiaceae dan Ophiglossaceae (Ebihara 2011). Kajian 
ini bertujuan untuk mengkarakterisasi morfologi Paku Kawat Lycopodiella cernua dari Provinsi Riau serta menganalisis sekuen DNA menggunakan primer $r b c l$.

\section{Metode Penelitian}

\section{Pengambilan sampel}

Pengambilan sampel di lapangan dilakukan dengan metode eksplorasi. Untuk kajian morfologi sampel yang diambil adalah individu dewasa yang sudah menghasilkan spora. Sampel didokumentasikan dan dibuat herbarium. Nama ilmiah dan sinonim dicek di situs www.theplantlist.org. Sedangkan untuk analisis DNA sampel yang diambil adalah daun muda. Sampel dimasukan kedalam plastik dan diberi label, kemudian sampel disimpan dalam lemari pendingin 4C sampai digunakan. Tabel 1 menyajikan sampel yang diamati

Tabel 1. Sampel Lycopodiella cenua untuk karakterisasi morfologi

\begin{tabular}{|c|c|c|}
\hline \multicolumn{2}{|c|}{ No } & \multirow[t]{2}{*}{ Kode spesimen } \\
\hline & Lokasi & \\
\hline 1 & Panam, Pekanbaru & $\begin{array}{lr}\text { LCP*, } & \text { LCP2, } \\
\text { LCP3, } & \text { Nery } \\
\text { 2017; } & \text { LCP4 } \\
\text { Nery 2018 } & \end{array}$ \\
\hline 2 & $\begin{array}{l}\text { Bagan Siapi Api, } \\
\text { Rokan Hilir }\end{array}$ & $\begin{array}{l}\text { LCB1, } 2017 \\
\text { Nery \& Kusnita }\end{array}$ \\
\hline 3 & Koto Gasip, Siak & $\begin{array}{l}\text { LCS1, LCS2 Nery } \\
2017\end{array}$ \\
\hline 4 & Pandau, Kampar & LCK Nery 2018 \\
\hline & pel yang digunakan & uk isolasi DNA \\
\hline $\begin{array}{l}\text { An } \\
\text { Ge } \\
\text { Un } \\
\text { DN } \\
\text { am } \\
\text { ele } \\
\text { per } \\
\text { DN } \\
\text { Jak }\end{array}$ & $\begin{array}{l}\text { lisis DNA dilakukan } \\
\text { etika, Jurusan } \\
\text { yersitas Riau, yait } \\
\text { A, elektroforesis h } \\
\text { lifikasi mengg } \\
\text { troforesis hasil amp } \\
\text { buatan sekuen DN } \\
\text { dilakukan di PT } \\
\text { rta). }\end{array}$ & $\begin{array}{l}\text { di Laboratorium } \\
\text { iologi FMIPA } \\
\text { meliputi isolasi } \\
\text { il isolasi DNA, } \\
\text { lakan PCR, } \\
\text { fikasi PCR serta } \\
\text { (untuk sekuen } \\
\text { enetiak Science, }\end{array}$ \\
\hline
\end{tabular}

Isolasi DNA dan elekroforesis hasil isolasi: Isolasi DNA dilakukan menggunakan DNA isolation Kit (Thermo Fisher Scientific). DNA hasil isolasi kemudian di cek dengan metode elekroforesis menggunakan agrose
$0.8 \%$ dalam Bufer TAE. Untuk mengetahui kuantitas DNA maka digunakan marker 100 bp (Vivantis).

Amplifikasi PCR dan elekroforesis hasil PCR

Polymerase Chain Reaction (PCR) dilakukan. dengan menggunakan Gradient Master Cycle Eppendorf. Komponen PCR mengacu pada protokol Dream Taq Green PCR Master Mix (Thermo Fisher Scientific). Primer yang digunakan pada amplifikasi disajikan pada Tabel 2.

Tabel 2. Sekuen Primer $r b c l$ untuk analisi PCR

\begin{tabular}{ll}
\hline Primer & \multicolumn{1}{c}{ Sekuen } \\
\hline rbcla-F & ATGTCACCACAAACAGAGACT \\
& AAAGC \\
rbcla-R & CTTCTGCTACAAATAAGAATC \\
& GATCTCTCA \\
\hline Sumber: & Hasebe et al. 1994; Maloukh et al. \\
2017. &
\end{tabular}

Siklus PCR mengacu pada kajian Watto et al. (2016) dengan modifikasi, yaitu sebagai berikut: Denaturasi awal $\left(94^{\circ} \mathrm{C}\right) 2$ menit, 30 siklus (Denaturasi $\left(94{ }^{\circ} \mathrm{C}\right) 1$ menit, Annealing primer $\left(56{ }^{\circ} \mathrm{C}\right) \quad 1$ menit $)$, Pemanjangan akhir $\left(72{ }^{\circ} \mathrm{C}\right) \quad 10$ menit, Penyimpanan $4{ }^{\circ} \mathrm{C}$. Hasil PCR dilanjutkan dengan elektroforesis menggunakan $1.5 \%$ agarose dengan buffer TAE. Untuk mengetahui kantitas dan kualitas hasil PCR digunakan marker 100 bp dan $1 \mathrm{~KB}$ (Vivantis).

\section{Sekuen DNA dan Analisis BLAST}

Hasil PCR kemudian dilanjutkan dengan melakukan sekuen (PT Genetika Science). Hasil sekuen berupa Chromas file, diedit dengan software Biological Sequence Alligment Editor (BioEdit). dan disajikan dalam bentuk Fasta file. Kemudian dilanjutkan dengan analisis Basic Local Alligment Search Tool (BLAST) untuk mengetahui keserasian sekuen rbcl dengan data di NCBI. Pembuatan pohon kekerabatan juga dilakukan dengan BLAST berdasarkan BLAST pairwise alignment dengan metode fast minimum evolution. 
Tabel 3 menunjukan situs software Chromas, BioEdit dan BLAST.

Tabel 3. Situs software Chromas, BioEdit dan BLAST

\begin{tabular}{cl}
\hline Program & \multicolumn{1}{c}{ situs } \\
\hline Chromas & https://technelysium.com.au/ \\
& wp/chromas/ \\
BioEdit & http://www.mbio.ncsu.edu/Bi \\
& oEdit/bioedit.html \\
BLAST & https://blast.ncbi.nlm.nih.gov/ \\
& Blast.cgi \\
\hline
\end{tabular}

\section{Hasil Dan Pembahasan}

\section{Taxonomic treatment}

Lycopodiella cernua (L.) Pic. Serm.

Webbia 23(1): 1661968.

Deskripsi: Terestrial. Rhizom merayap, panjang, bercabang merayap atau tegak mencapai $100 \mathrm{~cm}$, warna hijau. Daun mikrofil, isophilus, menyelubungi batang dan cabang, ujung runcing dan melengkung ke atas, ukuran sekitar $0.5 \times 2.5-4.0 \mathrm{~mm}$. Strobili terminal pada ujung cabang, sekitar $9-10 \mathrm{~mm}$, melengkung ke bawah.

\section{Sinonim}

Lepidotis cernua (L.). P. Beauv., Lycopodiella cernua var. cernua, Lycopodiella boryanum A. Rich., Lycopodium capillaceum (Spring) Hieron, Lycopodium cernuum L. Lycopodium cernuum var capillaceium Spring., Lycopodium cernuum var. panamanse Nessel, Lycopodium cernuum var. watsonianum Nessel, Lygodium hesschii Mull. Har., Lygodium moritzii O.F. Mull., Pahilhanhea capillacea (Spring) Holub, Palhinhaea cernua (L.) Franco \& Vasc.

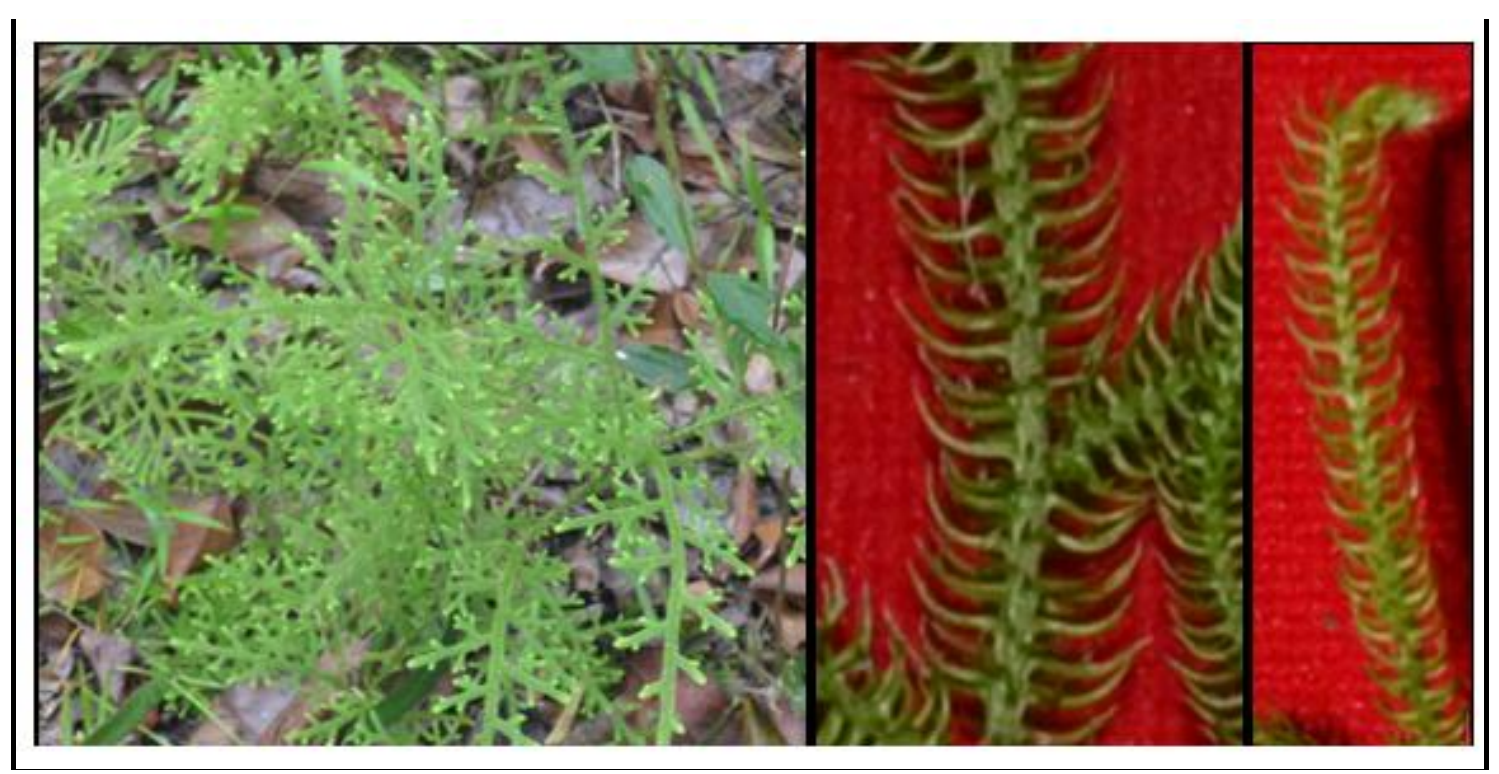

Gambar 1. Morfologi Lycopodiella cernua dari Provinsi Riau. Kiri: Habitus, tengah : daun pada btang utama, kanan : daun pada ujung cabang yang mendukung strobilus.

\section{Amplifikasi PCR}

Hasil amplifikasi PCR fragmen rbcl dari Lycpodiella cernua menunjukan pita tunggal dengan panjang sekitar $650 \mathrm{bp}$ (Gambar 2). Setelah ampifikasi PCR, dilanjutan dengan proses sekuen DNA.

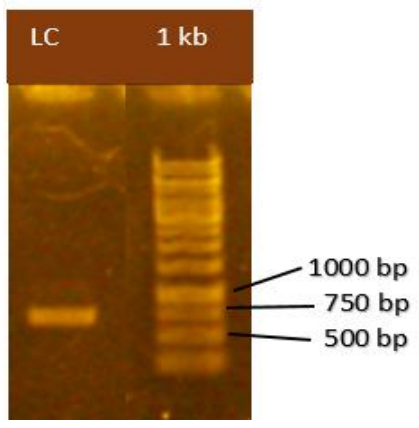


Gambar 2. Hasil amplifikasi PCR fragmen rbcl Lycopodiella cernua

\section{Sekuen DNA dan BLAST}

Hasil sekuen disajikan dalam Chromas file (gambar 3) dalam bentuk kromatogram. Kromatogram hasil sekuen mengunakan primer rbcla-F menunjukan hasil yang baik hal ini ditunjukan dengan adanya peak tunggal untuk setiap basanya.

Sekuen fragmen rbcl dari Lycopodiella cernua yang diperoleh menggunakan primer rbcla-F dan rbcla- $R$ diedit menggunakan BioEdit. Kemudian sekuen disimpan dalam Fasta File untuk dilanjutkan dengan analisis BLAST. Tabel 4 menunjukan hasil BLAST Paku Kawat Lycopodiella cernua dari Riau dengan sekuen rbcl dari aksesi yang tersimpan dalam data NCBI dengan nilai keserasian 99 $\%$ dengan spesies Lycopodiella glaucescens Lcopodiella pendulina, Palhinhaea tomentosa dan juga spesiemen dari jenis yang sama (Lycopodiella . cernua) Dari tabel tersebut dapat diketahui deskripsi sekuen yang disesajajarkan, nilai Max Score, Total Score, persentase Query Coverage, E Value, persentase Identity serta no aksesi.

Pada deskripsi diuraikan mengenai nama jenis dan fragmen yang diamplifikasi, yaitu jenis yang tergolong genus Lycopodiella dan Palhinhaea. Kedua genus ini tergolong dalam famili yang sama yaitu Lyccopodiaceae (Zhang \& Iwatzuki 2013). Selain nama jenis, pada deskripsi juga diketahui bahwa fragmen yang teramplikasi sesuai dengan data pada NCBI yaitu fragmen $\mathrm{rbcl}$. Untuk nilai Max Score menunjukan score keserasian tertinggi segmen yang disejajarkan dari sekuen yang sama pada database (Fassler \& Cooper 2011). Sedangkan persentase Query Coverage (QC) menunjukan persentase nukelotida yang serasi dengan sekuen yang ada di database NCBI. Pada tabel 4 diketahui nilai QC berkisar pada 92\% sampai $98 \%$.

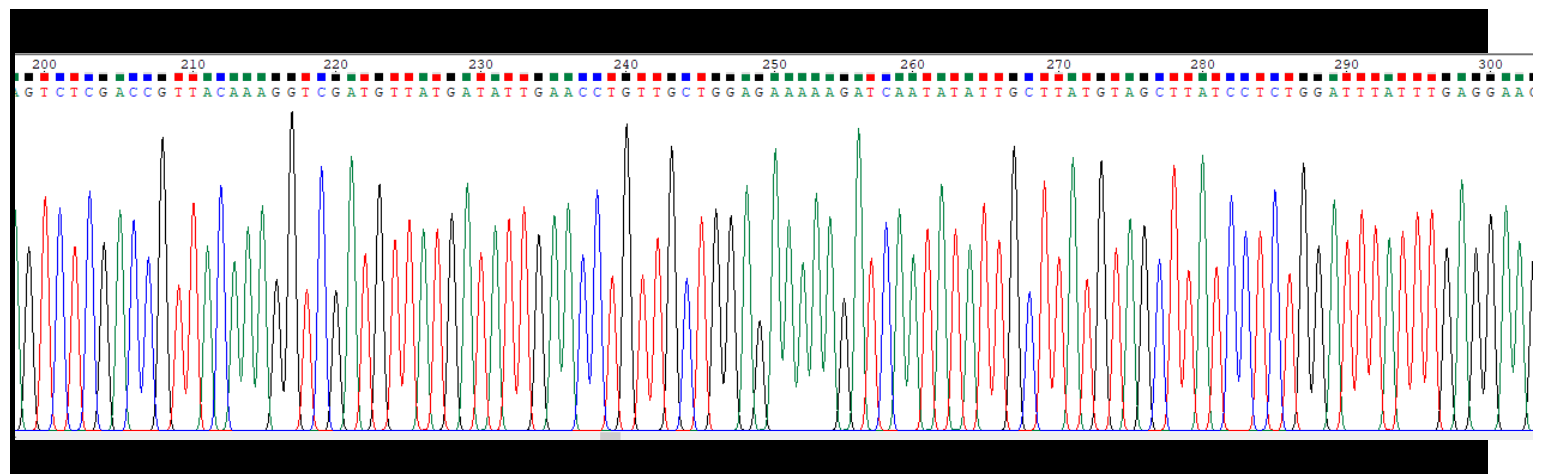

Gambar 3. Bagian kromatogram hasil sekuen fragmen rbcl Lycopodiella cernua (200 - 300 bp).

Nilai Expectation Value (EV) menggambarkan jumlah perbedaan pensejajaran dengan skor yang sesuai yang diharapkan ada pada database (Fassler \& Cooper 2011). Semakin tinggi nila EV maka semakin tinggi perbedaan sekuennya, sedangkan nilai EV yang mendekati 0 menujukkan tingkat homologi sekuen yang tinggi. Pada tabel 4 diketahui bahwa nilai EV pada semua aksesi adalah 0.0. Sedangkan persentase Identity (ID) merupakan persentase kesamaan tertinggi dari suatu segmen sekuen dengan subyek sekuen yang sama. Pada kajian ini nilai ID
$99 \%$ dijumpai pada 6 aksesi (Tabel 3), 4 aksesi merupakan genus Lycopodiella dan 2 aksesi dari genus Palhinhaea.

Gambar 4 menunjukkan contoh pensejajaran sekuen Lycopodiella cernua dari Provinsi Riau dengan salah satu aksesi yang mempunyai keserasian $99 \%$ yaitu Lycopodiella glaucescens. Panjang nukleotida dari Lycopodiella cernua Riau yang termaplifikasi menggunakan primer rbcl adalah 643 bp. Hasil pensejajaran pada gambar 4 menjukan bahwa keserasian sekuen dimulai pada urutan nukeotida ke 35. Dari 609 nukleotida yang disejajarkan, 
terdapat 605 nukleotida yang serasi dan 4 gap.

Pada sekuen rbcl Lycopodiella cernua dari Provinsi Riau, gap dijumpai pada urutan nukelotida ke 620, 623, 632 dan 635. Gap pada sekuen DNA menunjukan adanya mutasi, baik itu insertion (penyisipan) maupun deletion (pengurangan) suatu nukeotida, atau yang dikenal dengan istilah indels (Evans \& Warnow 2018). Menurut Yamuna \&
Elakkiya (2015) adanya gap pada sekuen DNA saat proses pensejajaran ditandai dengan tanda dash seperti terlihat pada gambar 4, hal ini bertujuan untuk mneyamakan panjang dari sekuen yang disejajarkan.

Tabel 4. Hasil BLAST fragmen rbcl Lycopodiella cernua dari Riau

\begin{tabular}{|c|c|c|c|c|c|c|}
\hline Description & $M S$ & $T S$ & $\begin{array}{r}Q C \\
(\%) \\
\end{array}$ & $E \boldsymbol{V}$ & $\begin{array}{l}I D \\
(\%)\end{array}$ & $A C C$ \\
\hline $\begin{array}{l}\text { Lycopodiella glaucescens chloroplast } \mathrm{rbcl} \\
\text { gene, partial }\end{array}$ & 1114 & 1114 & $98 \%$ & 0.0 & $99 \%$ & AJ133260.1 \\
\hline $\begin{array}{l}\text { Lycopodiella pendulina chloroplast rbcL gene, } \\
\text { partial }\end{array}$ & 1104 & 1104 & $97 \%$ & 0.0 & $99 \%$ & AJ133259.1 \\
\hline $\begin{array}{l}\text { Lycopodiella cernua chloroplast rbcL gene, } \\
\text { partial }\end{array}$ & 1077 & 1077 & $93 \%$ & 0.0 & $99 \%$ & AJ133258.1 \\
\hline $\begin{array}{l}\text { Palhinhaea cernua ribulose-1,5-biphosphate } \\
\text { carboxylase/oxugenase large subunit (rbcl) } \\
\text { gene, partial cds; chloroplast }\end{array}$ & 1076 & 1076 & $93 \%$ & 0.0 & $99 \%$ & KJ773661.1 \\
\hline $\begin{array}{l}\text { Palhinhaea tomentosa ribulose-1,5- } \\
\text { bisphosphate carboxylase/oxygenase large } \\
\text { subunit (rbcL) gene, partial cds; chloroplast }\end{array}$ & 1058 & 1058 & $93 \%$ & 0.0 & $99 \%$ & MG560497.1 \\
\hline $\begin{array}{l}\text { Lycopodiella cernua chloroplast rbcL gene for } \\
\text { ribulose-1,5-bisphosphate } \\
\text { carboxylase/oxygenase large subunit, partial } \\
\text { cds, specimen_voucher: TNS: } 759265\end{array}$ & 1050 & 1050 & $92 \%$ & 0.0 & $99 \%$ & AB574625.1 \\
\hline
\end{tabular}

Keterangan : MS = Max Score, $\mathrm{TS}=$ Total Score, $\mathrm{QC}=$ Query coverage, EV = Expected Value, ID = Identity, $\mathrm{ACC}=$ Accession

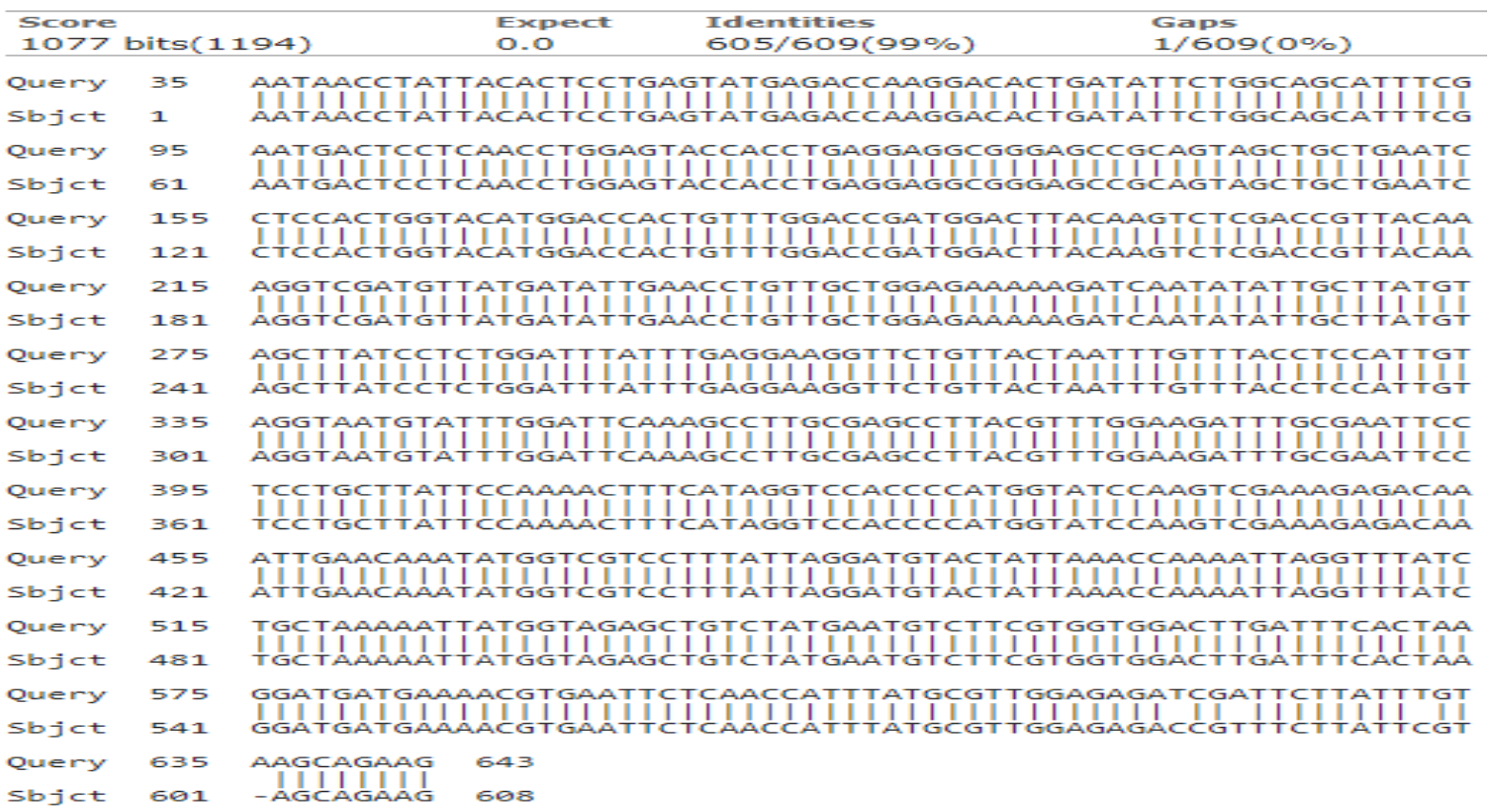


Gambar 4. Hasil pensejajaran sekuen DNA fragmen rbcl dari Lycopodiella cernua (query) menggunakan BLAST dengan aksesi dari NCBI (Sbjct) (tanda panah menunjukan gap)

Gambar 5 merupakan pohon filogenetik dari Lycopodiella cernua dari Provinsi Riau dengan 6 aksesi dari NCBI (Seperti yang disajikan pada tabel 4). Pohon ini diperoleh menggunakan BLAST pairwise alignment dengan metode fast minimum evolution. Menurut Yamuna \& Elakkiya (2015), BLAST pairwise alignment bertujuan untuk mengidentifikasi bagian sekuen yang mempunyai kesamaan, yang dapat menunjukan hubungan fungsional, structural dana tau evolusi antara dua sekuen DNA. Sedangkan metode fast minimum evolution merekonstruksi pohon dengan jarak evolusi terpendek.

Pada gambar 5 menunjukan Lycopodiella cernua (LCPNery) berada pada pangkal pohon, kemudian pohon terbagi menjadi 2 klad yang masing masing klad terdiri dari 3 aksesi. Aksesi Lycopodiella cernua (AJ133258.1) Palhinhaea cernua (KJ773661.1) dan Lycopodiella cernua (AB574625.1) membentuk sebuah klad dan mempunyai jarak evolusi yang lebih dekat dengan Lycopodiella cernua (LCPNery). Berdasarkan data dari situs www.theplantlist.org, nama Palhinhaea cernua sebenarnya merupakan sinonim dari
Lycopodiella cernua. Oleh karena itu, hasil kajian ini mendukung status taksonomi Palhinhaea cernua yang mempunyai keserasian sekuan DNA fragmen rbcl yang sangat tinggi dengan jenis Lycopodiella cernua. Klad kedua terdiri dari aksesi Lycopodiella glaucescens (AJ133260.1), Lycopodiella pendulina (AJ133259.1) dan Palhinhaea tomentosa (MG560497.1). Aksesi terakhir dari genus Palhinhaea mempunyai hubungan kekerabatan yang lebih jauh dibandingkan 2 aksesi dari genus Lycopodiella.

\section{Kesimpulan}

Paku Kawat Lycopodiella cernua dari Provinsi Riau mempunyai karakteritik Hasil amplifikasi DNA Paku Kawat Lycopodiella cernua dari Provinsi Riau, menggunakan primer rbcl sudah sesuai dengan sekuen target dnegan panjang 643 bp. Analisis BLAST menunjukan bahwa pendekatan molekuler Paku Kawat sangat mendukung status taksonomi jneis yang dikaji.

\section{Lycopodiella cernua LCPNery}

Lycopodiella glaucescens AJ133260.1

Lycopodiella pendulina AJ133259.1

Palhinhaea tomentosa MG560497.1

Lycopodiella cernua AJ133258.1

Palhinhaea cernua KJ773661.1

Lycopodiella cernua AB574625.1

Gambar 5. Pohon filogenetik Cyathea contaminans (NeryR1) dengan 7 aksesi dari NCBI menggunakan BLAST pairwise alignment dengan metode fast minimum evolution. 


\section{Daftar Pustaka}

Bafeel, S.O, Arif, I.A., Baki, M.A., Al Homaidan, A.A, Al Farhan, A.H., Khan, H.A. 2012. DNA barcoding of arid wild plants using rbcL gene sequences. Genet Mol Res. 11(3):1934-41. doi: 10.4238/2012.July.19.12

Chuang, S. \& Hu, J. 2004 The Evolution of Chloroplast matK Genes, Including Identification of New Homologues from Ophioglossum petiolatum and Two Lycophytes Taiwania, 49(4): 273-287

Dubuisson, J., Hennequin, S., Douzery, E.J.P., Cranfill, R.B., Smith, A.R., \& Pryer, K.M. 2003. Rbcl Phylogeny Of The Fern Genus Trichomanes (Hymenophyllaceae), With Special Reference To Neotropical Taxa. Int. J. Plant Sci. 164(5):753-761.

Ebihara, A.. 2011. RbcL Phylogeny of Japanese Pteridophyte Flora and Implications on Infrafamilial Systematics Bull. Natl. Mus. Nat. Sci., Ser. B, 37(2), pp. 63-74, May 22, 2011

Evans, S. \& Warnow, T. 2018. 2Phylogenetic analyses of alignments with gaps . https://statistics.berkeley.edu/sites/d efault/files/tech-reports/807.pdf

Gielly, L. \& Taberlet, P. 1994. The Use of Chloroplast DNA to Resolve Plant Phylogenies: Noncoding versus rbcL Sequences Mol. Biol. Evol. 11(5):769-777.

Hasebe, M. 1995. Fern Phylogeny Based on rbcl Nucleotide Sequence. American Fern Journal 85(4): 134 - 181.

NCBI.2008. https://ncbi.nlm.nih.gov.

Sofiyanti N, D. Iriani, A.A. Roza. 2015a. Morfologi tumbuhan Paku di Taman
Hutan Raya Sultan Syarif Hasyim, Riau. Unri Press, Pekanbaru.

Sofiyanti, N. \& Isda, MN. 2017. Pengembangan Metode SEM dan analisis DNA dalam sistematika tumbuhan paku. Laporan PBK tahun I (Tidak dipublikasikan).

Sofiyanti, N. \& Isda, MN. 2018. Pengembangan Metode SEM dan analisis DNA dalam sistematika tumbuhan paku. Laporan PBK tahun II (Tidak dipublikasikan).

Wikstrom, N. \& Kenrick, P. 2000. Relationships of Lycopodium and Lycopodiella Based on Combined Plastid rbcL Gene and trnL Intron Sequence Data Systematic Botany 25(3): $495-510$

Wikstrom, N. \& Kenrick, P. 2001. Evolution of Lycopodiaceae (Lycopsida): Estimating Divergence Times from $r b c L$ Gene Sequences by Use of Nonparametric Rate Smoothing. Molecular Phylogenetics and Evolution 19(2): 177-186. https://doi.org/10.1006/mpev.2001.0 936.

Wikstrom, N. \& Kenrick, P. 2008. Phylogeny of epiphytic Huperzia (Lycopodiaceae): paleotropical and neotropical clades corroborated by $\mathrm{rbcL}$ sequences. Nordic Journal of Botany. https://doi.org/10.1111/j.17561051.2000.tb01561.x

Zhang, L.B. \& Iwatsuki, K. 2013. Lycopodiaceae. Pp. 13-34 in Z. Y. Wu, P. H. Raven \& D. Y. Hong, eds., Flora of China, Vol. 2-3 (Pteridophytes). Beijing: Science Press; St. Louis: Missouri Botanical Garden Press. 